Original Research Paper

\title{
Heterologous Expression and Characterization of Thermostable Levansucrase (BsSacB) from Bacillus subtilis BB03
}

\author{
${ }^{1,2}$ Viniti Vaidya, ${ }^{3}$ Gajjeraman Prabu and ${ }^{1} D$. Theertha Prasad \\ ${ }^{1}$ Department of Biotechnology, University of Agricultural Sciences, GKVK, Bengaluru 560065, Karnataka, India \\ ${ }^{2}$ Department of Biotechnology, Shivaji University, Vidyanagar, Kolhapur 416004, Maharashtra, India \\ ${ }^{3}$ Department of Biotechnology, School of Life Sciences, Karpagam University, \\ Pollachi Main Road, Eachanari Post, Coimbatore 641021, Tamil Nadu, India
}

Article history

Received: 30-09-2014

Revised: 30-10-2014

Accepted: 13-01-2015

Corresponding Author:

D. Theertha Prasad

Department of Biotechnology,

University of Agricultural

Sciences, GKVK, Bengaluru

560065, India

Email: dtprasadd@gmail.com

\begin{abstract}
Thermostable levansucrase encoding gene ( $\operatorname{sac} B)$ with its promoter was isolated from Bacillus subtilis BB03. BsSacB is composed of $1419 \mathrm{bp}$, encoding 473 amino acid residues and with promoter regions TTGCAA (-35) and TAGAAT (-10). The amino acid sequence analysis of $B S S a c B$ showed conserved motifs of microbial fructosyltransferase belonging to Glycoside Hydrolase family 68 (GH68). Comparative analysis of the protein structure was carried out with 3D model of BsSacB constructed using PyMol software. BsSacB gene was expressed in Escherichia coli and the purified enzyme demonstrated thermo stability up to $50^{\circ} \mathrm{C}$ with a high hydrolytic activity at $\mathrm{pH} 6.0$ and presence of $\mathrm{Ca}^{2+}$ promoted the activity by $15 \%$. An attempt was made to further characterize the thermostable recombinant levansucrase from B.subtilis BB03 using crude sucrose rich substrates. Optimal levan production was seen with molasses $(1.94 \pm 0.04 \mathrm{~g} / \mathrm{L})$ at 15 $\mathrm{h}$ as compared to cane juice $(1.0 \pm 0.01 \mathrm{~g} / \mathrm{L})$ at $12 \mathrm{~h}$. An increase in levan formation with gradual decrease in hydrolytic activity was distinctly evident in both the molasses and juice media.
\end{abstract}

Keywords: B.subtilis, Cane Juice, Cane Molasses, E.coli, Levan and Levansucrase

\section{Introduction}

Levans are prebiotic agents with potential health benefits, selectively support intestinal health and act as low calorie sweeteners (Byun et al., 2014; Kang et al., 2009). They are used as blending component in cosmetics to provide cell-proliferating and skin moisturizing effects (Abdel-Fattah et al., 2012). Due to their physical and biological functions as antitumor, anti-inflammatory agent, they have potential application in food and pharmaceutical industry (Yoon et al., 2004; Kim et al., 2005). Levans are water soluble fructo-oligosaccharides which form viscous solutions, hence used as emulsifier or encapsulating agent in cosmetics, biodegradable plastics, textile coatings and detergents (Kang et al., 2009).

Levans are synthesized by bacterial levansucrases which belong to GH68 family. They synthesize fructan oligosaccharides and levan by transferring fructosyl group of non-activated sucrose into fructan polymers with $\beta$ $(2 \rightarrow 6)$ linkage (Seibel et al., 2006). Levansucrases catalyze two different reactions-hydrolysis of sucrose and transfructosylation to form fructose polymers by releasing glucose (Ozimek et al., 2006; Goldman et al., 2008). Bacillus species like B. methylotrophicus, B.subtilis, B. amyloliquefaciens and B. megaterium, are reported to be good producers of levansucrases (Zhang et al., 2014; Seibel et al., 2006; Homann et al., 2007; Rairakhwada et al., 2010; Vaidya and Prasad, 2012). However, poor availability and low stability of characterized microbial enzymes generates the need for investigation on levansucrases with improved physico-chemical properties (Maiorano et al., 2008).

For industrial exploitation of the potential of these enzymes, it is essential to gain knowledge about their 
molecular and structural characteristics. Characterization, cloning and expression of levansucrase (SacB) from Bacillus sp. in a heterogeneous system like E.coli have been attempted. Studies on recombinant expression of levansucrase in gram positive bacterium like $B$. megaterium are in developing phase (Rairakhwada et al., 2010; Korneli et al., 2013). Several expression studies have been performed using E.coli system (Rairakhwada et al., 2010; Kang et al., 2005; Nakapong et al., 2013); however they require addition of IPTG to induce levansucrase production. Further, the availability of low cost media and sucrose substrate is a major constraint in levan production. The present study report the isolation of $B S S a c B$ from B.subtilis with its own promoter inducible in presence of sucrose that can effectively be expressed in E.coli. The results of the studies on effect of temperature, $\mathrm{pH}$, substrate concentration and utilization of alternate sucrose rich substrate on hydrolysis and trans fructoslysation activity using the recombinant $B s S a c B$ expressed in E.coli has been presented.

\section{Materials and Methods}

\section{Genomic DNA Isolation and Cloning of BsSacB Gene}

Genomic DNA of B.subtilis BB03, an isolate from the Banana peel, which produces thermostable levansucrase was isolated (Sambrook et al., 1989) and used as template for amplifying $B s S a c B$. Initially, the primers for $s a c B$ (LevF-5'GCACTGTCGCAAACTATCAC-3' and LevR5'ACGTGATGCCGTCAATCG3') were designed based on the reported $s a c B$ gene sequences of bacterial levansucrases (Velázquez-Hernández et al., 2009). PCR reaction was performed in a $25.0 \mu \mathrm{L}$ reaction volume containing $2.5 \mu \mathrm{L}$ of $10 \mathrm{X}$ Taq buffer $\mathrm{B}, 1.5 \mu \mathrm{L}$ of 25.0 $\mathrm{mM} \mathrm{MgCl} 2,1.0 \mu \mathrm{L}$ of $10 \mathrm{mM}$ dNTPs (2.5 mM each), 1.0 $\mu \mathrm{L}$ of each primer, $1.0 \mu \mathrm{L}$ of Taq DNA polymerase $(3.0$ $\mathrm{U} / \mu \mathrm{L}$; Bangalore Genei, India), $0.5 \mu \mathrm{L}$ of isolated genomic DNA $(0.3 \mu \mathrm{g} / \mu \mathrm{L})$ and reaction conditions of initial denaturation at $94^{\circ} \mathrm{C}$ for $5 \mathrm{~min}$, followed by 35 cycles of denaturation at $94^{\circ} \mathrm{C}$ for $1 \mathrm{~min}$, annealing at $66^{\circ} \mathrm{C}$ for $1 \mathrm{~min}$ and extension at $72^{\circ} \mathrm{C}$ for $1 \mathrm{~min}$ and a final extension at $72^{\circ} \mathrm{C}$ for $7 \mathrm{~min}$. The sequence of the amplicon obtained was analyzed on NCBI BLASTn, which showed homology with $s a c B$ of B.subtilis (X02730.1). Based on this, primers Lev 16F (5'GTTCTTTAGGCCCGTAGTCTG3') and Lev 19R (5'AATACGGTTAGCCATTTGCCTGC3') were designed and full length $s a c B$ along with the promoter was obtained. PCR amplification was performed and the products were sequenced. Amplicons were analyzed on $1 \%$ agarose/EtBr gel electrophoresis, purified using
QIAEX II gel extraction kit (QIAGEN, India) and ligated into $\mathrm{pTZ} 57 \mathrm{R} / \mathrm{T}$ vector (Fermentas, India) as per the manufacturer's instructions. Recombinant pTZ:BsSacB was transformed into E.coli DH5 $\alpha$. Positive colonies were analyzed by colony PCR using Lev16F and Lev19R primers as well as internal primers (Lev46F5'CCGATGAACATCAAAAAGTTTGC3'; Lev74R5'ATCTCTCAGCGTATGGTTATCC3'). Recombinant plasmid was isolated using QIAprep mini spin kit (QIAGEN) and sequenced using automated DNA sequencer (Mega BASE 500, Applied Biosystems) and verified with BLASTn analysis.

\section{Bioinformatic Analysis of BsSacB}

BLAST search was performed in NCBI (http://www.ncbi.nlm.nih.org) and protein prediction was performed in CBI (http://www.cbi.pku.edu.cn). Alignment of the $B S S a c B$ nucleotide and protein sequence with other structurally related levansucrase genes were performed using the ClustalW program. Phylogenetic tree was drawn with the Mega 4.0 program (Tamura et al., 2007). Coding region of $B s S a c B$ (Acc.no.CBI68350) was analyzed by PSI-BLAST program (Position specific interactive BLAST) to identify structure of related protein. Atomic coordinates of the $1 \mathrm{OYG}$ structure, solved at $1.5 \mathrm{~A}^{\circ}$ resolution, was used as a template for comparative modeling. Sequence and structural alignment of $B s S a c B$ with 1OYG Chain A was performed using ClustalW (http://www.ebi.ac.uk/Tools/msa/clustalw2/). Aligning was carried out without the insertion of gaps in the conserved secondary structural regions. Spatial restraints were derived and used in the three dimensional structure determination using PyMol molecular graphics software (www.pymol.org). The stereochemical quality of model was assessed by PROCHECK (Laskowski et al., 1993; www.ebi.ac.uk/thornton-srv/software/PROCHECK/) at the same resolution as in $1 \mathrm{OYG}$ structure. The overall stereo chemical quality of the model was assessed by Ramachandran plot analysis.

\section{Expression of Recombinant Levansucrase}

E.coli harboring pTZ:BsSacB was grown in LB medium at $37^{\circ} \mathrm{C}$ for $12 \mathrm{~h}$ and used for levansucrase expression analysis. After the $12 \mathrm{~h}$ growth, the cells were lyzed by freezing at $-80^{\circ} \mathrm{C}$ followed by thawing in $37^{\circ} \mathrm{C}$ water bath and vortexed for $5 \mathrm{sec}$., the freeze-thaw cycle was repeated 4 times respectively (modified with reference to Gay et al., 1983). This was followed by centrifugation at $12000 \times \mathrm{g}$ for $10 \mathrm{~min}$ at $4^{\circ} \mathrm{C}$. The freeze thaw method is found to separate the highly expressed recombinant protein from the bulk of endogenous E.coli proteins (Sangiliyandi and Gunasekaran, 2000). The 
supernatant obtained was brought to $60 \%$ (v/v) with respect to acetone. Protein precipitated was collected by centrifugation $17,000 \times \mathrm{g}$ for $15 \mathrm{~min}$ at $4{ }^{\circ} \mathrm{C}$, dissolved in $0.05 \mathrm{M}$ sodium phosphate buffer, $\mathrm{pH}$ 6.0. The extract was further purified using Zeba spin columns (Thermo scientific), centrifuged at 3,040 rpm for $2 \mathrm{~min}$. Protein concentration was determined at $280 \mathrm{~nm}$ using BSA as standard and analyzed by Native PAGE (Sambrook et al., 1989). The unstained gel was sliced into $5 \mathrm{~mm}$ bits and extracted in $100 \mu \mathrm{L} 50 \mathrm{mM}$ sodium phosphate buffer, pH6.0 and assayed for levansucrase activity by standard procedure described.

\section{Assay for Levansucrase and Levan Production}

Levansucrase activity was assayed in a reaction mixture containing $6.5 \mu \mathrm{L}$ of protein sample (100 $\mu \mathrm{g} / \mathrm{mL}$ ) and $50 \mathrm{mM}$ sodium phosphate buffer, pH6.0, containing $8.5 \%(\mathrm{w} / \mathrm{v})$ sucrose and $1.0 \mathrm{mM} \mathrm{CaCl}_{2}$ followed by incubation at $50^{\circ} \mathrm{C}$ for $60 \mathrm{~min}$ and the amount of glucose released was measured using glucose oxidase kit (Merck, India; Vaidya and Prasad, 2012). For levan production, assay mixture was incubated at $40^{\circ} \mathrm{C}$ for $12 \mathrm{~h}$. Levan produced was precipitated with 4 volume of ice-cold $70 \%$ aqueous ethanol and centrifuged at $17,400 \times \mathrm{g}$ at $5^{\circ} \mathrm{C}$. The resulting precipitate was re-suspended in sterile distilled water and heated at $80^{\circ} \mathrm{C}$ for $10 \mathrm{~min}$ followed by hydrolysis in $0.1 \mathrm{~N} \mathrm{HCl}$ at $80^{\circ} \mathrm{C}$ for $10 \mathrm{~min}$. After the hydrolysis, the levan content was assayed using $1 \%$ resorcinol reagent and expressed as fructose units (Viikari and Gisler, 1986).

\section{Levansucrase Activity and Stability}

Levansucrase activity and levan production profile was analyzed over a range of $\mathrm{pH} 5.0-9.0(50 \mathrm{mM}$ sodium acetate buffer of $\mathrm{pH} 5.0,50 \mathrm{mM}$ sodium phosphate buffer $\mathrm{pH}$ 6.0-7.0 and Tris-Cl buffer $\mathrm{pH}$ 8.0-9.0). Levansucrase was also analyzed for $\mathrm{pH}$ stability, ( $\mathrm{pH} 5.0-9.0)$ by pre-incubating the enzyme sample at appropriate $\mathrm{pH}$ for $15 \mathrm{~min}$ prior to the assay. Optimum temperature for the activity and levan formation was determined by incubating reaction mixture at $4-80^{\circ} \mathrm{C}$ under standard assay conditions. Temperature stability of the enzyme was tested by pre-incubation at above mentioned temperatures for 15 min and residual activity was measured.

To examine the effect of metal ions, levansucrase was pre-incubated for $60 \mathrm{~min}$ at $4^{\circ} \mathrm{C}$ with $1.0 \mathrm{mM}$ concentration of cations $\left(\mathrm{Mg}^{2+}, \mathrm{Cu}^{2+}, \mathrm{Ca}^{2+}, \mathrm{K}^{1+}, \mathrm{Mn}^{2+}\right.$; $\mathrm{Fe}^{3+}$ and $\mathrm{Hg}^{2+}$ ) prepared in $50 \mathrm{mM}$ sodium phosphate buffer, $\mathrm{pH}$ 6.0. Levansucrase activity and levan production profile was analyzed at different sucrose concentrations $(1.0-13.0 \% \mathrm{w} / \mathrm{v})$ in $50 \mathrm{mM}$ sodium phosphate buffer $\mathrm{pH} 6.0$ and temperature $\left(50^{\circ} \mathrm{C}\right.$ for sucrose hydrolase activity and $40^{\circ} \mathrm{C}$ for levan production). Michaelis constant $(\mathrm{Km})$ and velocity maximum (Vmax) was calculated. To determine the effect of enzyme concentration, enzyme solution (0$100 \mu \mathrm{g} / 10 \mu \mathrm{L})$ was spotted on agar plate (1.35\%) containing $8.5 \%(\mathrm{w} / \mathrm{v})$ sucrose and incubated overnight at $40^{\circ} \mathrm{C}$. Whitish slimy spots formed were photographed under UV light for better visualization. Effect of incubation time on levansucrase activity and levan produced was measured at every $3 \mathrm{~h}$ intervals for $24 \mathrm{~h}$.

\section{Cane Juice and Molasses as Substrate}

Cane molasses or cane juice as source of sucrose was used to assess levansucrase activity and levan production. Prior to analysis, cane molasses was clarified using $0.1 \mathrm{~N} \mathrm{H}_{2} \mathrm{SO}_{4}$ and $\mathrm{pH}$ was adjusted to 6.0 using $0.1 \mathrm{~N} \mathrm{NaOH}$. Cane juice was heated at $80^{\circ} \mathrm{C}$ for inactivating the innate invertase activity and filtered through Whatmann No. 3 filter paper. Clarified molasses or cane juice were analyzed for sucrose, glucose and fructose concentration by high performance liquid chromatography (Waters) using Ultra Amino column, Restek (150 mm length and $100 \mathrm{~A}^{\circ}$ pore size) with RI detector (Waters 410). E.coli -pTZ:BsSacB was grown in cane molasses and juice diluted to contain $1.0 \%$ sucrose, fortified with $0.2 \%$ yeast extract and $0.2 \%\left(\mathrm{NH}_{4}\right)_{2} \mathrm{SO}_{4}$ (Han and Watson, 1992) in $500 \mathrm{~mL}$ Erlenmeyer flasks at $37^{\circ} \mathrm{C}$ under shaking conditions at $150 \mathrm{rpm}$ for overnight. Gay et al. (1985) reported use of $\mathrm{sacB}$ as a counter selectable marker for E.coli and other gram negative bacteria. It was seen that the production of levansucrase in those microbial systems was lethal in presence of $5.0 \%$ sucrose in the medium. Similarly, higher sucrose concentration did not resulted in efficient cell growth in this system thus limiting our study for using sucrose concentration compatible with the growth. Further, growth was monitored by recording the $\mathrm{OD}$ at $600 \mathrm{~nm}$; enzyme from the harvested cells at regular intervals was assayed for levansucrase activity and levan production.

\section{Statistical Analysis}

All the parameter analyses were repeated with three independent biological samples. The data were analyzed by one-way Analysis of Variance (ANOVA) and the treatment means were compared by using Duncan's Multiple Range Test (DMRT) at $p \leq 0.05$. Data were expressed as Mean \pm Standard Error (SE). 


\section{Results and Discussion}

\section{Amplification and Sequence Analysis of BsSacb}

Many bacterial levansucrases have been expressed in heterologous system and assayed for their ability to produce levans (Caputi et al., 2013; van Hijum et al., 2004; Homann et al., 2007; Rairakhwada et al., 2010). Partial conserved domain of levansucrase encoding gene, $S a c B$ was amplified using the primers LevF and LevR from B.subtilis BB03 genomic DNA. BLASTn analysis of the amplicon ( $800 \mathrm{bp}$; Fig. 1) revealed sequence similarity with levansucrase encoded by sacN of B.subtilis (X02730.1; 98\%), sacB of B.subtilis (AY150365.1; 97\%), B.stearothermophilus (U34874.1; 95\%) and B.amyloliquefaciens (EU668142.1; 83\%). Further, primers Lev16F and Lev19R were designed based on the levansucrase gene sequences of B.subtilis (X02730.1) and PCR amplification resulted in a $\sim 1.8 \mathrm{~kb}$ fragment (Fig. 1a). The fragment was cloned into pTZ57R/T, giving pTZ:BsSacB. BsSacB gene (FN599519.1) contained promoter sequence, Ribosomal Binding Site (RBS) and protein coding region (Fig. 1b). BsSacB encodes for a putative protein having 473 amino acids with a predicted molecular weight of $52.9 \mathrm{kD}$. Based on the phylogenetic analysis, microbial fructosyltransferases have been classified into three groups-levansucrases from gram-positive, gram-negative microbes and fungi (Velázquez-Hernández et al., 2009). Bacterial levansucrases belongs to GH68 family with typical conserved motifs-VWDSW motif functioning as a catalytic nucleophile, EWSGS (sucrose box I), YLVFE for sucrose hydrolysis and transfructosylation and DEIER (catalytic center) (Fig. 2). Phylogenetic analysis of levansucrases show significant homology in nucleotide sequences from B.subtilis strains and Zymomonas mobilis (Fig. 3).

Three dimensional structure of $B s S a c B$ protein was compared with crystal structure of B.subtilis levansucrase (CBI68350.1, 1OYG_A chain) using PyMol Molecular Graphics Software and PROCHECK to quantify the residues in available zones of the Ramachandran plot. It was found that $87.8 \%$ of residues were located in the most favored zones, $10.7 \%$ in allowed regions, $1.0 \%$ in generously allowed regions and $0.5 \%$ (two residues) in disallowed region. Ramachandran plot characteristic and the goodness factors (quality of covalent and overall bond-angle distances) confirm this to be the best fit for the predicted model proposed for BsSacB (Fig. 4).

\section{Expression of BsSacB in E.coli}

Proteins from the recombinant E.coli having $p T Z: B s S a c B$ were analyzed by native-PAGE and ingel levansucrase activity. The protein band with levansucrase activity $(3.9 \mathrm{U} / \mathrm{mg})$ from the in-gel assay (Fig. 5) corresponded to the molecular weight of 52 $\mathrm{kDa}$ by SDS-PAGE which is in accordance with the predicted molecular weight. $B S S a c B$ encoded protein is typical to monomeric enzymes with the molecular weight ranging from of $46-73 \mathrm{kDa}$. However studies report that levansucrases from Rahnella aquatilis JMC-1683, Leuconostoc mesenteroides B-512 FMC and Actinomyces viscosus $\mathrm{T}-14 \mathrm{~V}$ exist as dimmers (Ohtsuku et al., 1992; Kang et al., 2005; Pabst, 1977)

\section{Effect of $\mathrm{pH}$ and Temperature on Levansucrase} Activity and Levan Synthesis

Levansucrase activity of $B s S a c B$ protein was maximum $(6.5 \mathrm{U} / \mathrm{mg})$ at $\mathrm{pH} \quad 6.0$ and the activity significantly reduced above $\mathrm{pH}$ 7.0. Eighty-seven percent of the activity was retained at $\mathrm{pH}$ 5.0. Optimum yield of levan was at $\mathrm{pH} 6.0$ which was observed to be $14.3 \mathrm{~g} / \mathrm{L}$ and reduced to $6.7 \mathrm{~g} / \mathrm{L}$ at $\mathrm{pH}$ 7.0 (Fig. 6a). Levansucrase activity was maximum at $50^{\circ} \mathrm{C}(10.6 \mathrm{U} / \mathrm{mg})$ and showed a steep decrease with increase in temperature above $50^{\circ} \mathrm{C}$. However, levan production was optimum at $40^{\circ} \mathrm{C}(10.8 \mathrm{~g} / \mathrm{L})$ and reduced drastically at $60^{\circ} \mathrm{C}(1.03 \mathrm{~g} / \mathrm{L}$; Fig. 6b). Similar difference was observed in optimum temperature for sucrose hydrolysis activity and levan formation with other recombinant levansucrase clones expressed in E.coli. Studies on $R$. aquatilis levansucrase showed hydrolase activity at $40^{\circ} \mathrm{C}$ and levan formation at $30^{\circ} \mathrm{C}$ (Kim et al., 1998). Levansucrase from B.amyloliquefaciens showed optimal activity at $30^{\circ} \mathrm{C}$ and levan production at $0-4^{\circ} \mathrm{C}$ (Rairakhwada et al., 2010). Studies by Hettwer et al. (1995) revealed that P.syringae levansucrase activity and levan formation was maximum at $60^{\circ} \mathrm{C}$ and $18^{\circ} \mathrm{C}$ respectively. Sangiliyandi and Gunasekaran (2000) reported the levansucrase activity at $60^{\circ} \mathrm{C}$ and levan synthesis at $30^{\circ} \mathrm{C}$ by Z.mobilis. However, BsSacB levansucrase was found to be tolerant over a wide $\mathrm{pH}$ and temperature range, stable over a $\mathrm{pH}$ range from 5.0 to 7.0 (Fig.7a) and temperature range from 4 to $50^{\circ} \mathrm{C}$ (Fig. $7 \mathrm{~b}$ ). These results put together suggest that $B s S a c B$ levansucrase shows higher thermal stability in hydrolytic activity as compared to that in transfructosylation reaction. However, it has been observed that at saturated levels, levan formed was found to rapidly hydrolyze by levansucrase itself at higher temperatures (Song et al., 1998). 


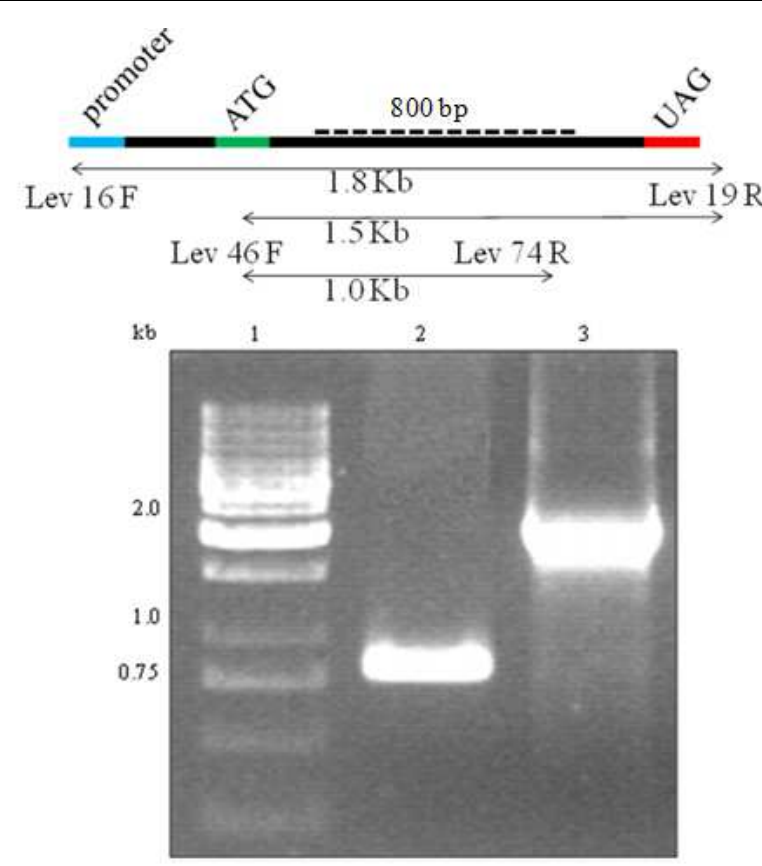

(a)

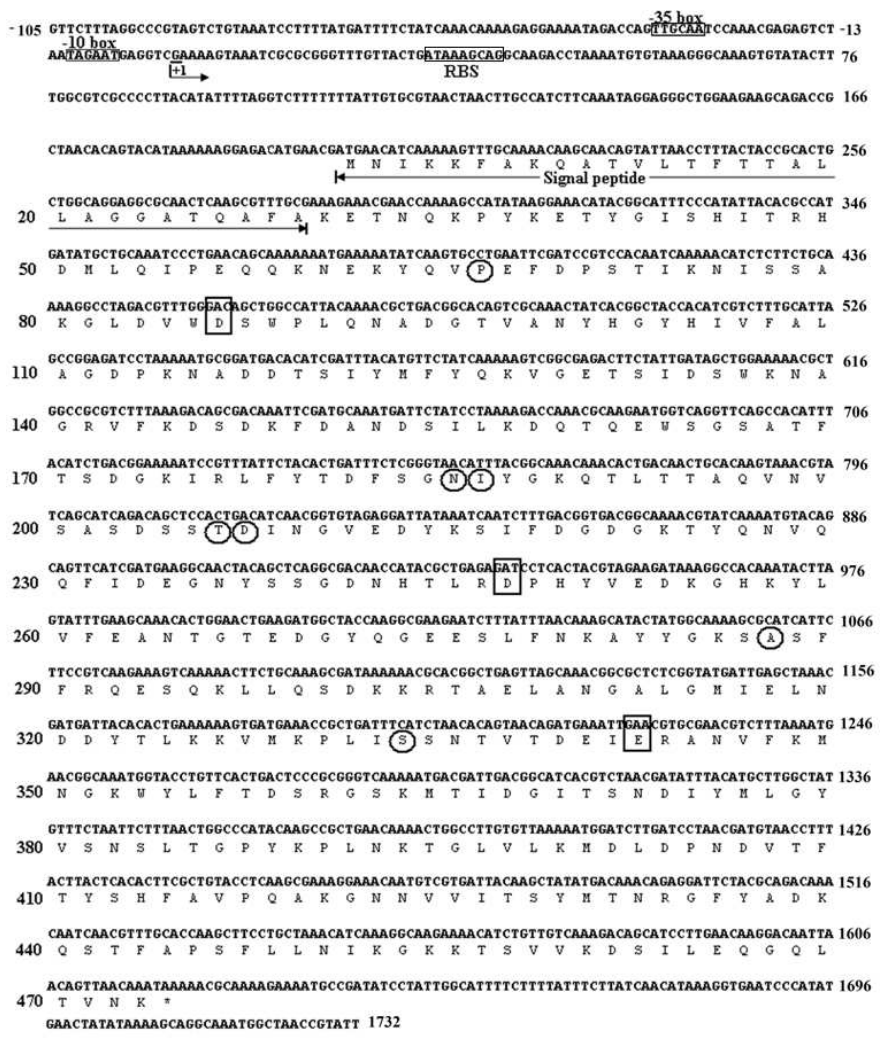

(b)

Fig. 1. (a) PCR amplification using B.subtilis BB03 genomic DNA as template, including schematic representation of designed primers. Lane 1: 1 kb DNA Ladder, Lane 2: PCR with primers Lev F and Lev R and Lane 3: PCR with primers Lev 16 F and Lev 19 R. (b) Nucleotide sequence and predicted amino acid sequence of the BSSacB gene from B.subtilis BB03. Nucleotides and amino acid residues are numbered on the left and right, respectively. The Ribosome Binding Site (RBS), -10 box, -35 box (in box), the active site residues (Asp86, Asp247, Glu342; in box), the amino acid changes (in circle), the stop codon $(*$ ) and the signal peptide sequences (horizontal arrows) are indicated 


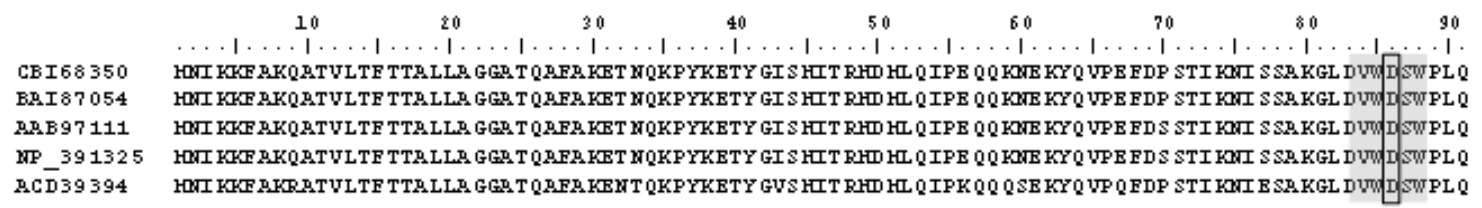

CEI68 350 BAI 87054 A.PB 97111 MP_ 391325 $\operatorname{RC} \bar{D} 39394$

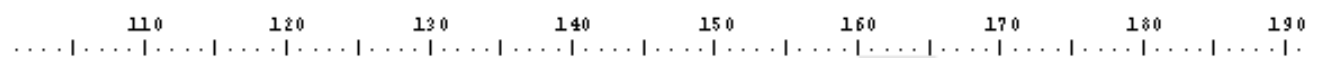

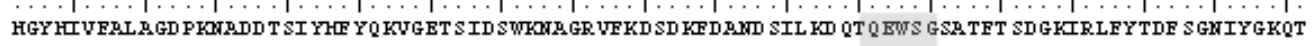

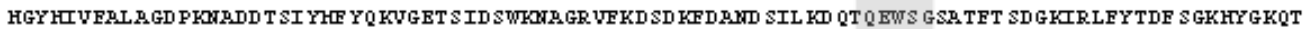

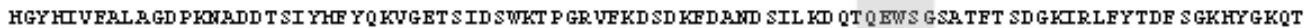
HGYFU UFA L GD PKAADD T SI YFF Y Q KVGET S ID SWROAGR UFKD SD KFD ARD SIL KD QT Q EWS GSA TFT SDGKIRLFYTDF SGKHYGKQT

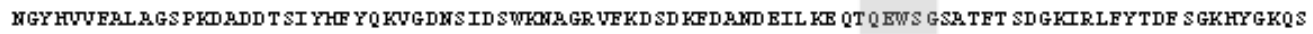

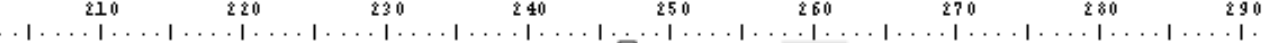

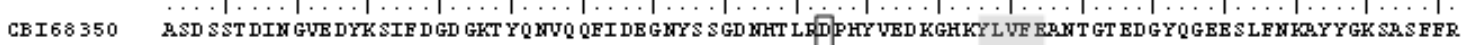

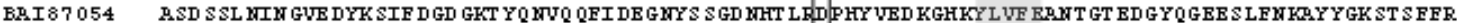

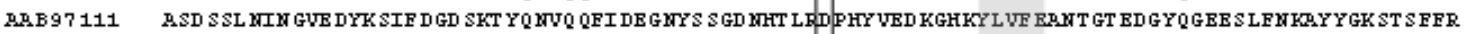

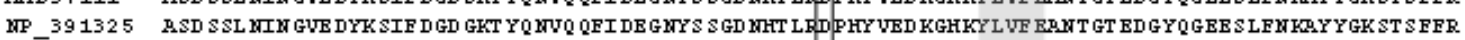

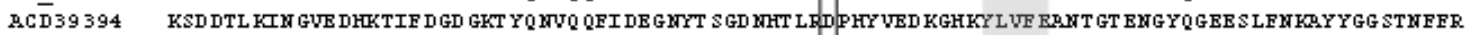

CBI68 350 BAI 87054 ARB 97111 NP_ 391325 $\operatorname{ACD} 39394$

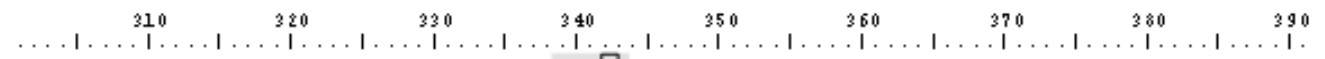

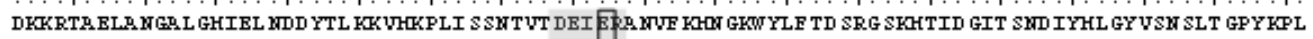

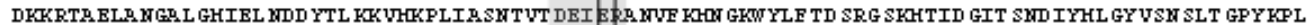

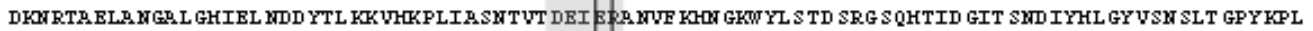

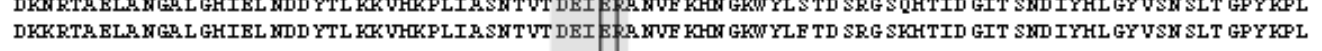

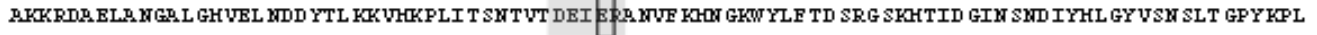

CEI68 350

BAI 87054 ARB 97111

MP_ 391325

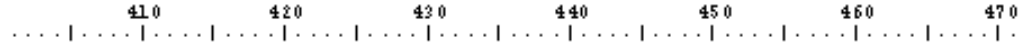

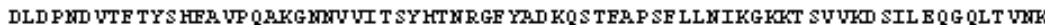

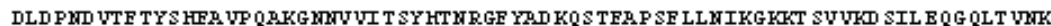

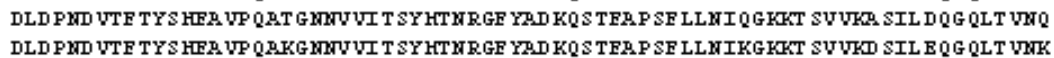

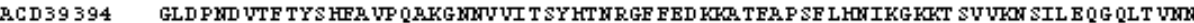

Fig. 2. Amino acid sequence alignment of Bacillus subtilis BB04 (CBI68350.1) with levansucrase from B.subtilis subsp. natto (BAI87054), B. stearothermophilus (AAB97111), B. subtilis str. 168 (NP 391325.1) and B. amyloliquefaciens (ACD39394) respectively. The amino acid residues are numbered on the left and ruled on top. The residues essential for the catalytic activity Asp 86 , Asp 247 and Glu342 are boxed. Region from 37-470 is designated as Glyco_hydro_68 family domain in Bacillus sp. The conserved motifs of microbial FTFs are indicated in shaded boxes

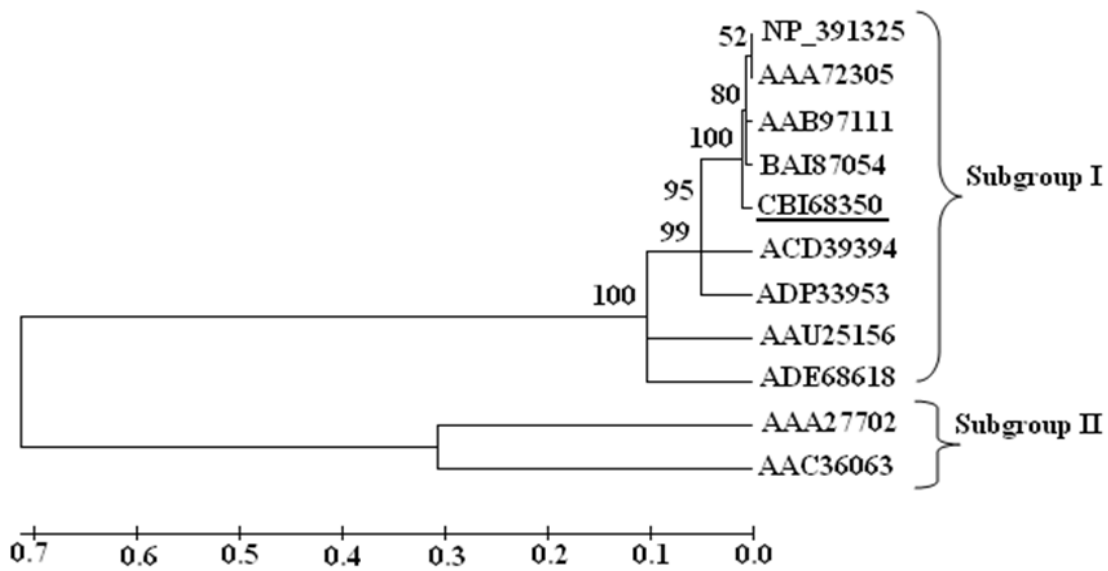

Fig. 3. Comparison of the deduced amino acid sequence of $B$. subtilis BB03 sacB with other levansucrases from gram-negative and gram-positive bacteria. Un-rooted dendrogram derived from the amino acid sequences. The tree was generated from a consensus of 1000 bootstrap replicates using neighbor joining method in MEGA 5 program. The scale bar indicates the relative amount of change along branches. The accession nos. of the sequences used in the comparison are indicated in the right margin, B.subtilis (BAI87054), B.subtilis (AAA72305), B.subtilis (NP_391325), B. atrophaeus (ADP33953), B. amyloliquefaciens (ACD39394), Geobacillus stearothermophilus (AAB97111), B. megaterium (ADE68618), B. licheniformis (AAU25156), Zymomonas mobilis (AAA27702) and Pseudomonas syringae (AAC36063) respectively 


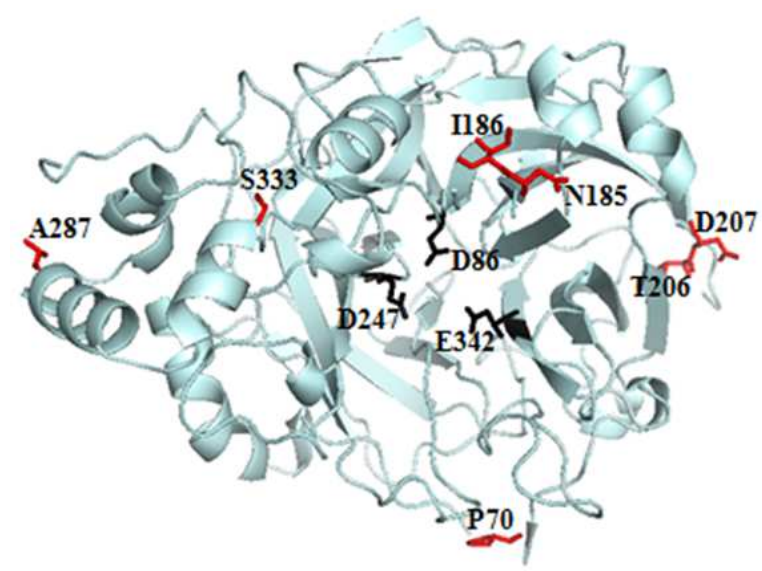

(a)

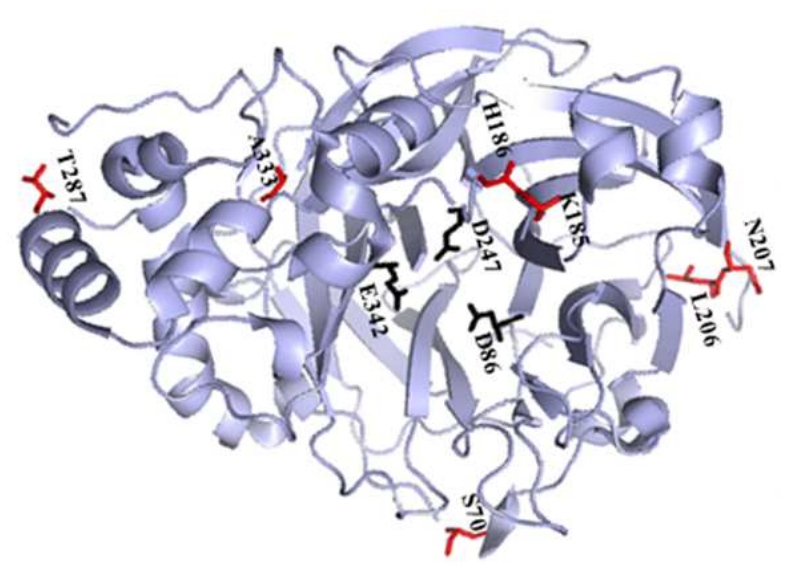

(b)

Fig. 4. The 3D structure of (a) thermostable B.subtilis BB03 levansucrase (CBI68350.1) was compared with (b) B.subtilis levansucrase (1OYG_A) using PyMol Molecular Graphics System. Essential active site residues (in black) were found to be conserved in both the structures and changes in amino acid residue were indicated in red

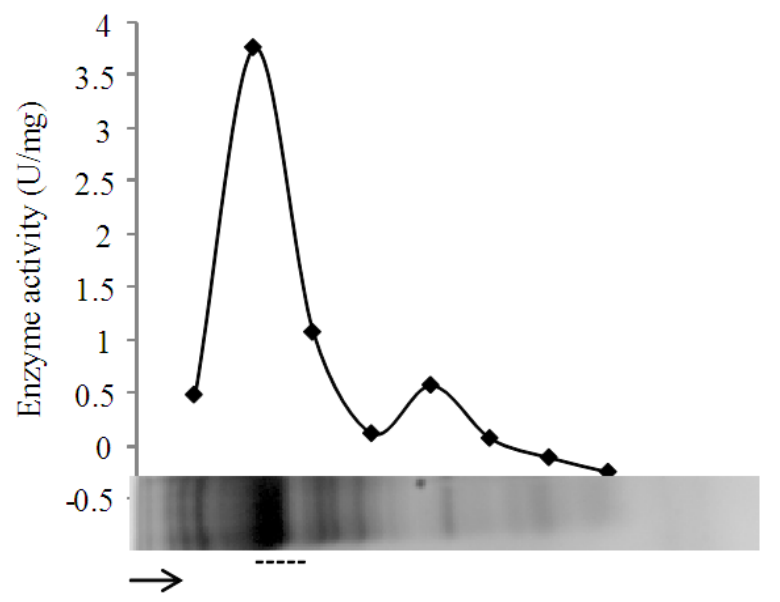

Fig. 5. In gel activity assay of E.coli - pTZ:BsSacB enzyme extract on native PAGE. Gel pieces were assayed for levansucrase activity. The arrow indicates the direction of the run. The dotted line indicates the gel piece showing maximum activity

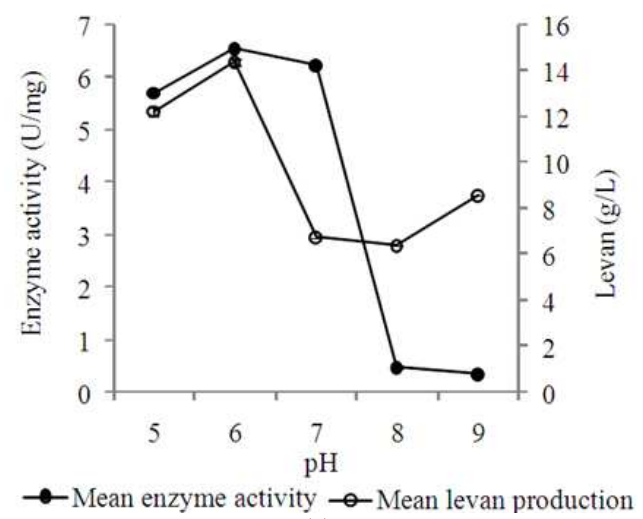

(a)

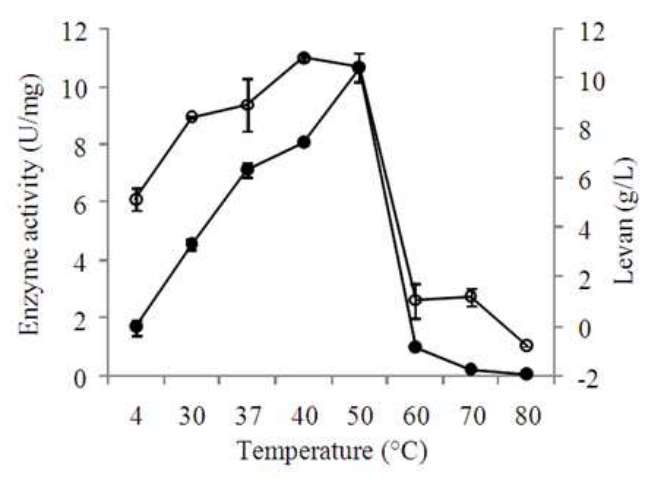

(b)

Fig. 6. Effect of $\mathrm{pH}$ and temperature on E.coli expressed recombinant FTF on levansucrase activity and levan formation Optimum (a) $\mathrm{pH}$ and (b) temperature was determined for levansucrase activity and levan formation. The enzyme was assayed at different $\mathrm{pH}(5.0$ to 9.0) and temperatures $\left(4^{\circ} \mathrm{C}\right.$ to $\left.80^{\circ} \mathrm{C}\right)$ under standard conditions 


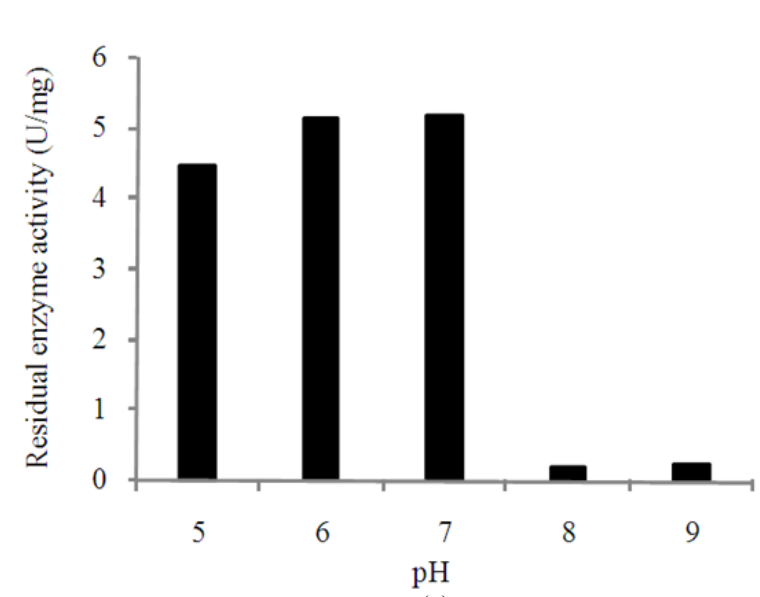

(a)

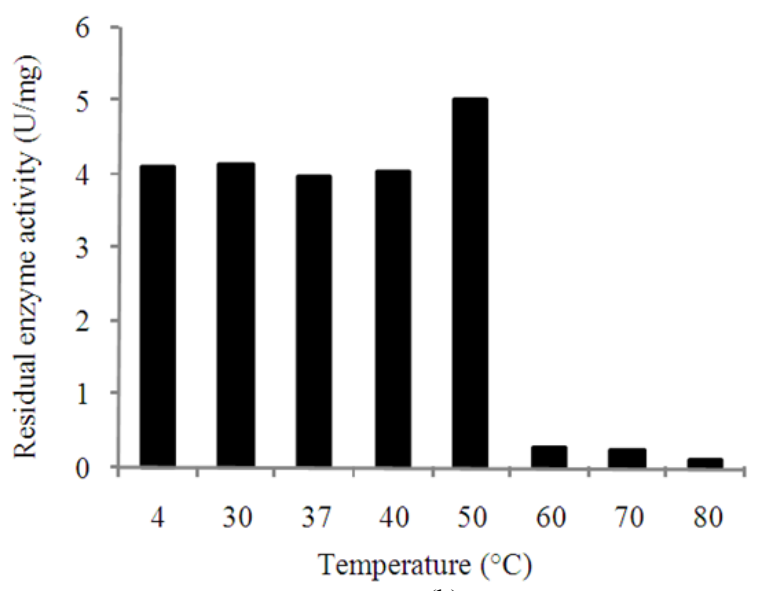

(b)

Fig. 7. pH stability (a) and thermal stability (b) of the enzyme was examined by pre-incubating the enzyme for 15 min at respective $\mathrm{pH}$ and temperatures followed by standard assay conditions

Table 1. Effect of cations and EDTA on E.coli expressed recombinant FTF on levansucrase activity and levan production

\begin{tabular}{|c|c|c|c|c|}
\hline Ion & $\begin{array}{l}\text { Relative activity }{ }^{a} \\
(\%)\end{array}$ & $\begin{array}{l}\text { Relative activity after EDTA } \\
\text { treatment }^{b}(\%)\end{array}$ & $\begin{array}{l}\operatorname{Levan}^{a} \\
(\%)\end{array}$ & $\begin{array}{l}\text { Levan after EDTA } \\
\text { treatment }^{b}(\%)\end{array}$ \\
\hline None & 100.0 & 27.1 & 100.0 & -- \\
\hline $\mathrm{Ca}$ & 115.0 & 44.6 & 129.1 & 12.2 \\
\hline $\mathrm{Na}$ & 100.3 & 27.3 & -- & -- \\
\hline $\mathrm{K}$ & 94.4 & 29.0 & -- & -- \\
\hline $\mathrm{Mg}$ & 60.8 & 28.8 & -- & -- \\
\hline $\mathrm{Fe}$ & 40.3 & 26.5 & -- & -- \\
\hline $\mathrm{Mn}$ & 36.7 & 27.3 & -- & -- \\
\hline $\mathrm{Hg}$ & 32.3 & 26.7 & -- & -- \\
\hline
\end{tabular}

*reaction mixtures were incubated with $1.0 \mathrm{mM}$ cation for $10 \mathrm{~min}$

**reaction mixtures were pre-incubated with $0.5 \mathrm{mmol} / \mathrm{L}$ EDTA for $10 \mathrm{~min}$ followed by $1.0 \mathrm{mmol} / \mathrm{L}$ cations and assayed for residual levansucrase activity

\section{Effect of Metal Ions on Enzyme Activity and Levan Formation}

Most of the levansucrases require metal ions as cofactors. Lactobacillus reuteri, Leu. mesenteroides and B.subtilis levansucrases require $\mathrm{Ca}^{2+}$ (van Hijum et al., 2004; Ozimek et al., 2006; Morales-Arrieta et al., 2006; Velázquez-Hernández et al., 2009) whereas $\mathrm{Fe}^{3+}$ can also act as an substitute cofactor for levansucrase by certain B.subtilis strains (Chambert et al., 1990). Table 1 shows the effects of metals ions on levansucrase activity and respective levan yield. $\mathrm{Ca}^{2+}$ enhanced levansucrase activity by $15 \% . \mathrm{Na}^{+}$and $\mathrm{K}^{+}$did not show any significant effect. $\mathrm{Mg}^{2+}, \mathrm{Fe}^{3+}, \mathrm{Mn}^{2+}$ and $\mathrm{Hg}^{2+}$ ions inhibited levansucrase activity more than $50 \%$. The competition and replacement of a majority of smaller bivalent cations with $\mathrm{Ca}^{2+}$ may result in a deformed tertiary structure and may be the reason for an inhibitory effect (Waldherr et al., 2008). EDTA blocked more than $70 \%$ of the enzyme activity. However, in presence of $\mathrm{Ca}^{2+}$, activity was restored to $44 \%$ of its initial activity. Levan production was $29 \%$ higher in presence of $\mathrm{Ca}^{2+}$ compared to other metal ions. Sequence alignments of family GH68 proteins showed the presence of calcium ion-binding site and Asp339 was identified as key amino acid residue coordinating $\mathrm{Ca}^{2+}$ binding (Meng and Futterer, 2003) in majority of levansucrases from Gram-positive bacteria (Ozimek et al., 2006) including BsSacB (Fig. 2).

\section{Effect of Sucrose Concentration on Enzyme Activity and Levan Formation}

Maximum levansucrase activity and levan formation was observed at $8.5 \%$ sucrose (Fig. 8). Activity was slightly reduced at higher sucrose concentration (9.0$13 \%)$. Studies have shown that at higher sucrose concentration, the transfructosylation is a preferred reaction with noticeable decrease in hydrolase activity (Ammar et al., 2002). L. sanfranciscensis TMW levansucrase expressed in E.coli, showed maximum levansucrase activity at $6.8 \%$ sucrose, however increased levan production was observed with increase in sucrose concentration above $7.0 \%$ (Tieking et al., 2005). Km of the $B s S a c B$ levansucrase was $42.5 \mathrm{mmol} / \mathrm{L}$ of sucrose, 


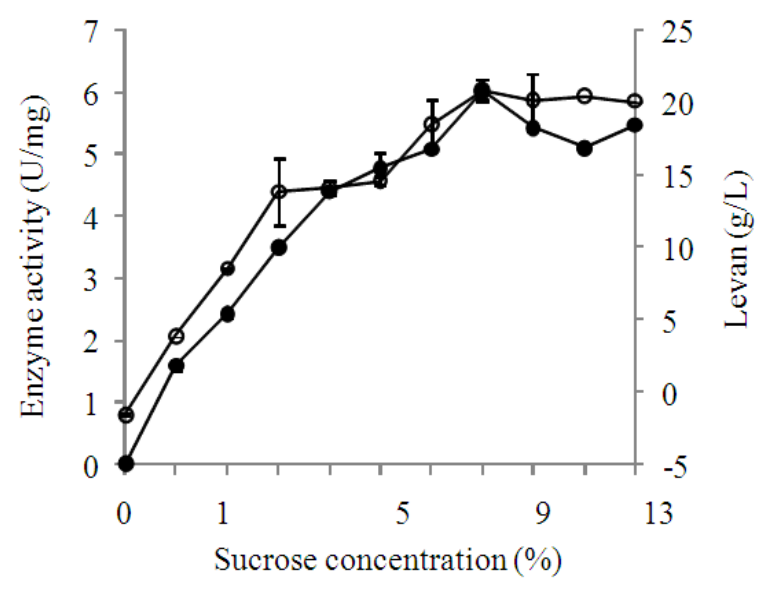

Mean enzyme activity - Mean levan production

Fig. 8. Effect of sucrose concentration on E.coli expressed recombinant FTF on levansucrase activity and levan formation

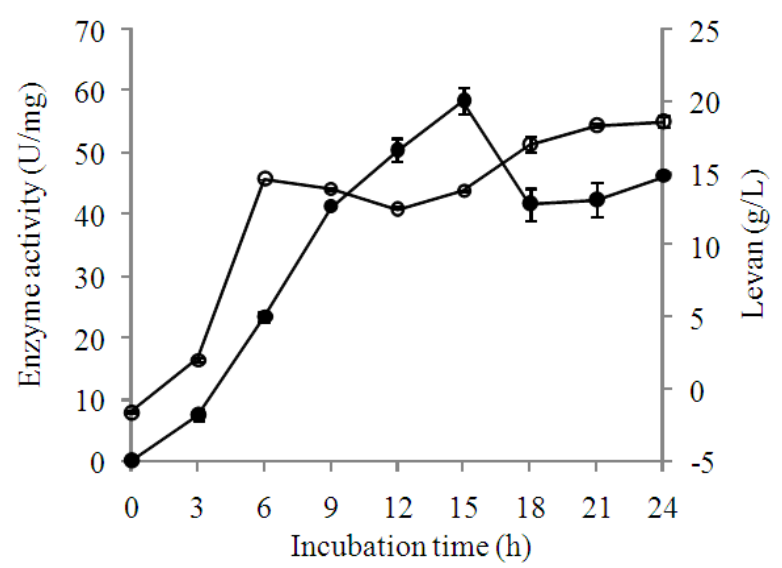

$\rightarrow-$ Mean enzyme activity $\rightarrow$-Mean levan production

Fig. 9. Effect of different incubation time on sucrose hydrolysis activity and levan formation by E.colipTZ: $B s S a c B$ levansucrase

Vmax of $5.909 \mathrm{U} / \mathrm{mg}$ and exhibited sigmoidal curve with substrate concentration. $K \mathrm{~m}$ value reported for levansucrase was on par with enzymes from $B$. amyloliquefaciens, $47 \mathrm{mmol} / \mathrm{L}$ (Rairakhwada et al., $2010)$ and $R$. aquatilis JCM-1683 $50 \mathrm{mmol} / \mathrm{L}$ (Ohtsuku et al., 1992) but differed with levansucrases from Leu. mesenteroides B-512 FMC $26 \mathrm{mmol} / \mathrm{L}$ (Kang et al., 2005), Z. mobilis_ $160 \mathrm{mmol} / \mathrm{L}$ (Yanase et al., 1992) and Pseudomonas syringae _122 mmol/L (Hettwer et al., 1995).

\section{Effect of Incubation Time}

Maximum levansucrase activity was at $15 \mathrm{~h}$ of incubation time and decreased. However a steep increase in levan production was observed up to $6 \mathrm{~h}$ followed by gradual increase till $24 \mathrm{~h}$ with $8.5 \%$ (w/v) sucrose (Fig. 9).

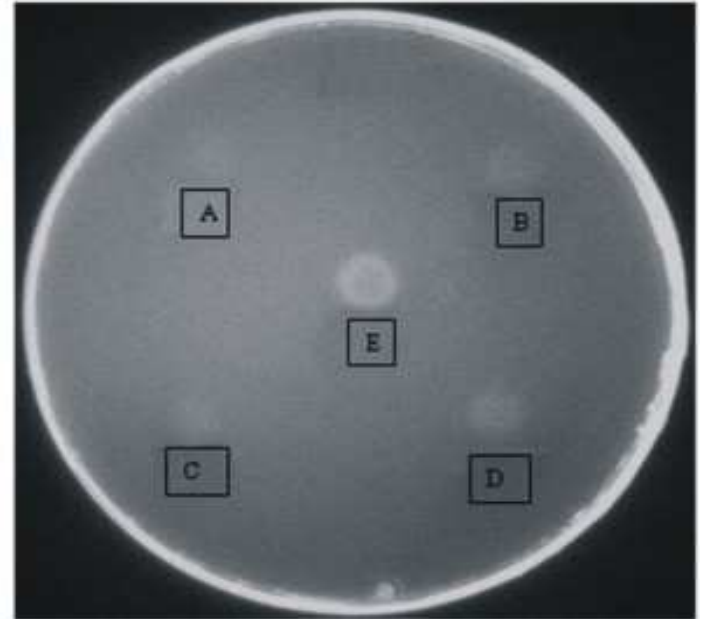

Fig. 10. Effect of concentration of E.coli expressed recombinant FTF on levan production. A: 20 B: 40 C: 60 D: 80 and E: $100 \mu \mathrm{g}$ of enzyme was spotted on $8.5 \%(\mathrm{w} / \mathrm{v})$ sucrose agar plate. Levan formation was seen as whitish layer formed at the spotted area

Similar study reports that recombinant levansucrase from $B$. amyloliquefaciens synthesized levan till $24 \mathrm{~h}$ (Rairakhwada et al., 2010). However, wild type $s a c B$ from Z. mobilis B14023 was expressed in E.coli produced levan from the initial period of fermentation and reached a maximum concentration at $16 \mathrm{~h}(6.8 \mathrm{~g} / \mathrm{L}$ and $10.7 \mathrm{~g} / \mathrm{L}$ respectively) (Ananthalakshmy and Gunasekaran, 1999). The production capacity of recombinant $R$. aquatilis levansucrase was found to reduce with prolonged incubation time at saturated levels of levan (Kim et al., 1998). Since levansucrase has both transfructosylation and hydrolase activity, hydrolysis of fructans can be expected at higher concentration of levans (Song et al., 1998). Sucrose agar plate assay for levan production showed whitish slimy layer and was directly proportional with the enzyme concentration (Fig. 10) which is on par with our earlier observations (Vaidya and Prasad, 2012). Similarly, levan production from B.subtilis NRC 33a levansucrase was also related to effective concentration of enzyme. The conversion of fructose to levan was $84 \%$ and the sucrose concentration was critical to levan synthesis (Abdel-Fattah et al., 2005).

Enzyme Synthesis and Levan Production by Levansucrase from E.coli -pTZ:BsSacB Grown in Cane Molasses and Cane Juice

Attempts have been made to commercially produce fructooligosaccharides utilizing agro-industrial byproducts rich in sucrose (Sangeetha et al., 2005). Levan are useful prebiotic compounds with enormous application in food and pharma industry and reduction in its production cost has high impact on its industrial production and usage (Kucukasik et al., 2011). Cane molasses and juice contained 23.0 and $18.0 \%$ sucrose respectively. HPLC 
analysis revealed about $2.8 \%$ fructose and $2.9 \%$ glucose in cane molasses. E. coli harboring BsSacB showed comparatively slow growth in fortified cane molasses and cane juice formulated to $1.0 \%$ sucrose (attained stationary phase in 9 and $15 \mathrm{~h}$, respectively; Fig. 11a and b) as compared to wild type. In previous study, B.subtilis strain BB04 was grown in cane molasses and juice diluted to $6 \%$ sucrose, giving higher levan production (11.32 g/L and $4.81 \mathrm{~g} / \mathrm{L}$, respectively) after $12 \mathrm{~h}$ (Vaidya and Prasad, 2012). Hydrolase activity in cane molasses drastically decreased after $6 \mathrm{~h}$, whereas levan production continued up to $15 \mathrm{~h}$ and remained almost constant (Fig. 11c). In cane juice, levan formation showed increasing trend till $12 \mathrm{~h}$ (Fig. 11d) and correlated with decrease in levansucrase activity. Thus, it was evident that with decreasing hydrolytic activity the transfructosylation activity increased which was also seen with sucrose as substrate. However, maximal levan production obtained using sucrose $(8.5 \mathrm{~g} / \mathrm{L})$ was higher than that of cane molasses $(1.94 \mathrm{~g} / \mathrm{L})$ and cane

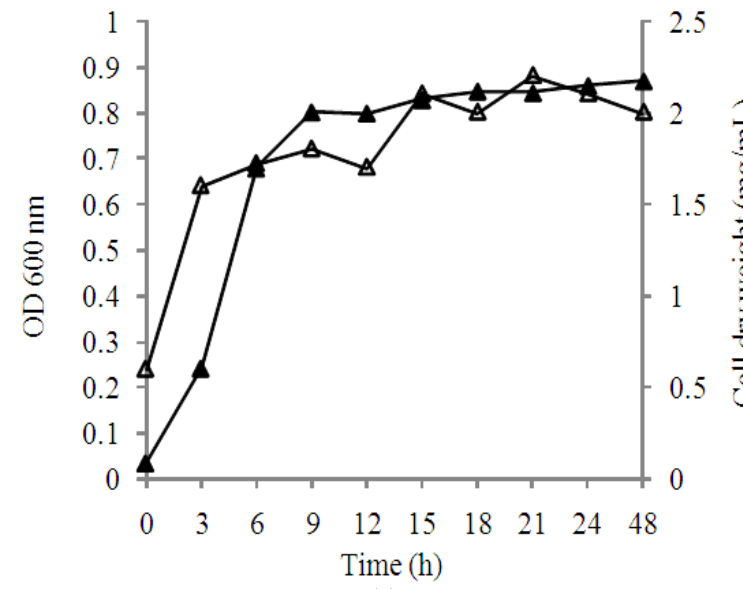

(a)

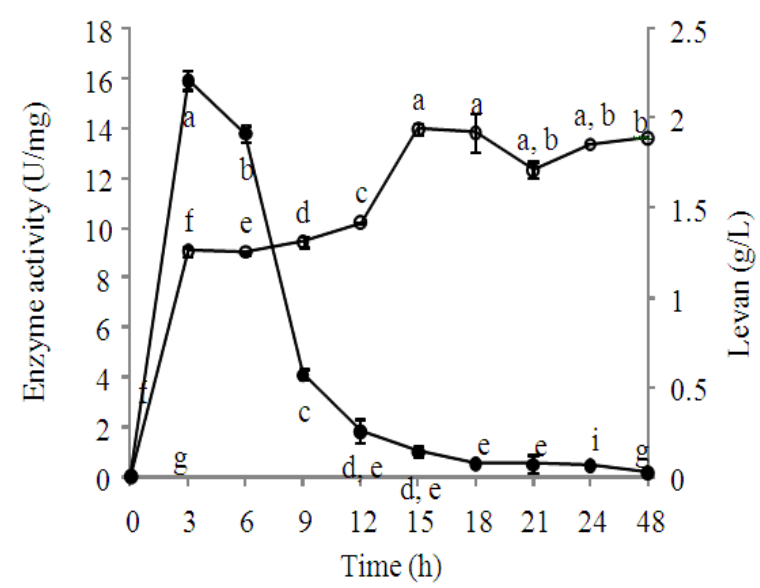

(c) juice $(1.0 \mathrm{~g} / \mathrm{L})$. Further clarification of media is necessary for production level levan yield. Halomonas sp. was grown in sugar beet and starch molasses pretreated by different methods. The levan yield in sugar beet after the clarification and pre-treatment $(1.31 \mathrm{~g} / \mathrm{g}$ of dry cell weight) was greater than before $(0.72 \mathrm{~g} / \mathrm{g}$ of dry cell weight) (Kucukasik et al., 2011). Microbacterium laevaniformans was used for levan production (10.4 $\mathrm{g} / \mathrm{L}$ in $48 \mathrm{~h}$ ) using date syrup as source of sucrose and the results suggest that increase in fermentation time caused a decrease in levan yield (Moosavi-Nasab et al., 2010). Higher levan formation in cane molasses might be due to the presence of readily available fructose in the medium unlike cane juice. Levansucrase from Halomonas sp. effectively synthesized levan from sugar beet $(4.19 \mathrm{~g} / \mathrm{L})$ but not from starch molasses $(3.68 \mathrm{~g} / \mathrm{L})$ as source of sucrose and was attributed to readily available sucrose content in sugar beet, a limitation in starch molasses (Kucukasik et al., 2011).

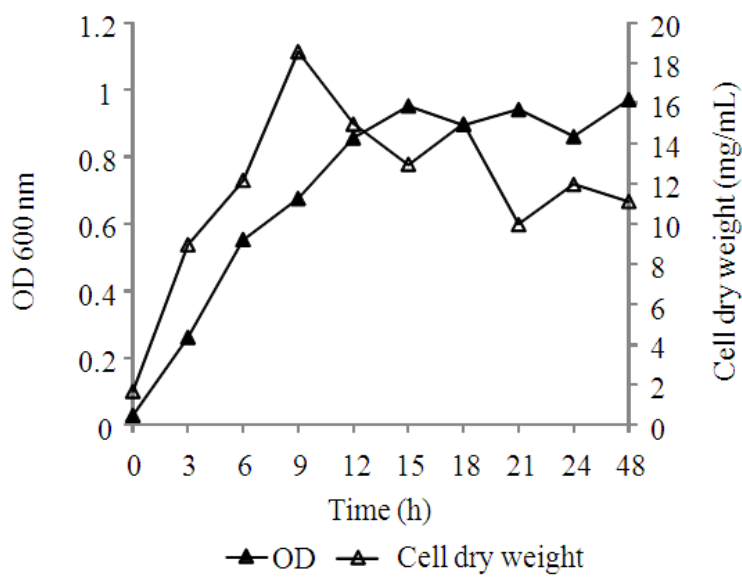

(b)

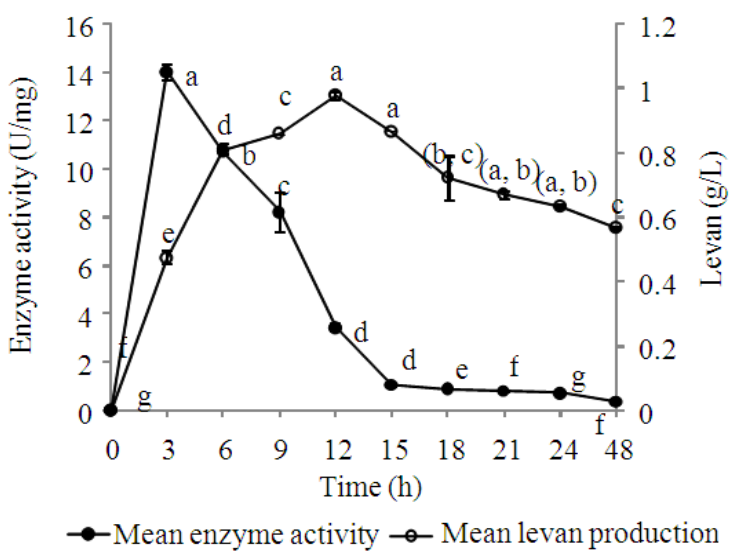

(d)

Fig. 11. Study of E.coli expressed FTF activity using fortified cane molasses (a, c) and cane juice (b, d). Determination of $\mathrm{OD}_{600 \mathrm{~nm}}$ and cell dry weight $(\mathrm{a}, \mathrm{b})$; levansucarse activity and levan content (c, d). Points with superscripts a-g differ from each other significantly at $p<0.05$ 


\section{Conclusion}

The present study reports the functional characterization of a thermostable levansucrase from B.subtilis BB03 expressed in E.coli. The recombinant enzyme was stable over a wide $\mathrm{pH}$ range and showed considerable activity in cane molasses and juice. Several studies reported lower levan yield using crude low-cost sources as compared to sucrose (Han and Watson, 1992; Moosavi-Nasab et al., 2010; Oliveira et al., 2007) with wild type system, this study was an attempt to obtain levan production in a heterologous system using $s a c B$ gene with its own promoter without IPTG induction. Further studies are needed for analyzing different media formulations which may include better clarification strategies for cane molasses and juice, in order to obtain higher levan production. However, this study provides useful knowledge about the functional and molecular properties of a thermostable levansucrase from Bacillus expressed in a heterologous system and demonstrate the potential use of low cost sucrose sources like cane molasses and juice for levan yield.

\section{Funding Information}

This research work was supported by the grant from Life Sciences Research Board, Government of India (DLS/81/48222/ LSRB-204/FSB/2009) to Dr Prasad and Senior Research fellowship to Ms Vaidya.

\section{Author's Contributions}

Dr. D. Theertha Prasad: Project was conceived, planned and co-ordinated.

Ms Vinithi Vaidya: The experiments were executed.

Dr. GR Prabhu: Bioinformatics analysis.

\section{Ethics}

The authors declare that there is no conflict of interests regarding the publication of this paper.

\section{References}

Abdel-Fattah, A.F., D.A.R. Mahmoud and M.A.T. Esawy, 2005. Production of levansucrase from Bacillus subtilis NRC 33a and enzymic synthesis of levan and fructooligosaccharides. Cur. Microbiol., 51: 402-407.

DOI: $10.1007 / \mathrm{s} 00284-005-0111-1$

Abdel-Fattah, A.M., A.M. Gamal-Eldeen, W.A. Helmy and M.A. Esawy, 2012. Antitumor and antioxidant activities of levan and its derivative from the isolate Bacillus subtilis NRC1aza. Carbohydr. Poly., 89: 314-322. DOI: 10.1016/j.carbpol.2012.02.041
Ammar, Y.B., T. Matsubara, K. Ito, M. Iizuka and T. Limpaseni et al., 2002. Characterization of a thermostable levansucrase from Bacillus sp. TH4-2 capable of producing high molecular weight levan at high temperature. J. Biotechnol., 99: 111-119. DOI: $10.1016 / \mathrm{S} 0168-1656(02) 00160-8$

Ananthalakshmy, V.K. and P. Gunasekaran, 1999. Overproduction of levan in Zymomonas mobilis by using cloned sacB gene. Enz. Microb. Technol., 25: 109-115. DOI: 10.1016/S0141-0229(99)00018-6

Byun, B.Y., S.J. Lee and J.H. Mah, 2014. Antipathogenic activity and preservative effect of levan $(\beta-2, \quad 6$-fructan), a multifunctional polysaccharide. Int. J. Food Sci. Tech., 49: 238-245. DOI: $10.1111 /$ ijfs. 12304

Caputi, L., S.A. Nepogodiev, M. Malnoy, M. Rejzek and R.A. Field et al., 2013. Biomolecular characterization of the levansucrase of Erwinia amylovora, a promising biocatalyst for the synthesis of fructooligosaccharides. J. Agric. Food Chem., 61: 12265-12273. DOI: $10.1021 /$ jf4023178

Chambert, R., F. Benyahia and M.F. Petit-Glatron, 1990. Secretion of Bacillus subtilis levansucrase. Fe(III) could act as a cofactor in an efficient coupling of the folding and translocation processes. Biochem. J., 265: 375-382.

Gay, P., D.L. Coq, M. Steinmetz, E. Ferrari and J.A. Hoch, 1983. Cloning structural gene sacB, which codes for exoenzyme levansucrase of Bacillus subtilis: Expression of the gene in Escherichia coli. J. Bacteriol., 153: 1424-1431.

Gay, P., D.L. Coq, M. Steinmetz, T. Berkelman and C.I. Kado, 1985. Positive selection procedure for entrapment of insertion sequence elements in gramnegative bacteria. J. Bacteriol., 164: 918-921.

Goldman, D., N. Lavid, A. Schwartz, G. Shoham and D. Danino et al., 2008. Two active forms of Zymomonas mobilis levansucrase an ordered microfibril structure of the enzyme promotes levan polymerization. J. Biol. Chem., 283: 32209-32217. DOI: $10.1074 /$ jbc.M805985200

Han, Y.W. and M.A. Watson, 1992. Production of microbial levan from sucrose, sugarcane juice and beet molasses. J. Ind. Microbiol. Biotechnol., 9: 257-260. DOI: 10.1007/BF01569633

Hettwer, U., M. Gross and K. Rudolph, 1995. Purification and characterization of an extracellular levansucrase from Pseudomonas syringae pv. phaseolicola. J. Bacteriol., 177: 2834-2839.

Homann, A., R. Biedendieck, S. Gotze, D. Jahn and J. Seibel, 2007. Insights into polymer versus oligosaccharide synthesis: Mutagenesis and mechanistic studies of a novel levansucrase from Bacillus megaterium. Biochem. J., 407: 189-198. DOI: 10.1042/BJ20070600 
Kang, S.A., U. Chun and K.H. Jang, 2005. Effects of dietary fructan on cecal enzyme activities in rats. Biotech. Bioproc. Eng., 10: 582-586.

DOI: $10.1007 / \mathrm{BF} 02932298$

Kang, S.A., K.H. Jang, J.W. Seo, K.H. Kim and Y.H. Kim et al., 2009. Levan: Applications and Perspectives. In: Microbial Production of Biopolymers and Polymer Precursors: Applications and Perspectives, Rehm, B. (Ed.), Caister Academic, Wymondham, ISBN-10: 1904455360, pp: 145-161.

Kim, K.H., C.B. Chung, Y.H. Kim, K.S. Kim and C.S. Han et al., 2005. Cosmeceutical properties of levan produced by Zymomonas mobilis. J. Cosmet. Sci., 56: 395-406.

Kim, M.G., J.W. Seo, K.B. Song, C.H. Kim and B.H. Chung et al., 1998. Levan and fructosyl derivatives formation by a recombinant levansucrase from Rahnella aquatilis. Biotech. Lett., 20: 333-336. DOI: 10.1023/A:1005310926399

Korneli, C., F. David, R. Biedendieck, D. Jahn and C. Wittmann, 2013. Getting the big beast to work-systems biotechnology of Bacillus megaterium for novel highvalue proteins. J. Biotechnol., 163: 87-96.

DOI: 10.1016/j.jbiotec.2012.06.018

Kucukasik, F., H. Kazak, D. Guney, I. Finore and A. Poli et al., 2011. Molasses as fermentation substrate for levan production by Halomonas sp. Appl. Microbiol. Biotechnol., 89: 1729-1740. DOI: $10.1007 / \mathrm{s} 00253-010-3055-8$

Laskowski, R.A., M.W. Macarthur, D.S. Moss and J.M. Thornton, 1993. PROCHECK: A program to check the stereochemical quality of protein structures. J. App. Cryst., 26: 283-291.

DOI: $10.1107 / \mathrm{S} 0021889892009944$

Maiorano, A.E., R.M. Piccoli, E.S. da Silva and M.F.D.A. Rodrigues, 2008. Microbial production of fructosyltransferases for synthesis of pre-biotics. Biotech. Lett., 30: 1867-1877.

DOI: $10.1007 /$ s10529-008-9793-3

Meng, G. and K. Futterer, 2003. Structural framework of fructosyl transfer in Bacillus subtilis levansucrase. Nat. Struct. Molecular Biol., 10: 935-941. DOI: $10.1038 / \mathrm{nsb} 974$

Moosavi-Nasab, M., B. Layegh, L. Aminlari and M.B. Hashemi, 2010. Microbial production of levan using date syrup and investigation of its properties. World Acad. Sci. Eng. Technol., 4: 1022-1028.

Morales-Arrieta, S., M.E. Rodríguez, L. Segovia, A. López-Munguía and C. Olvera-Carranza, 2006. Identification and functional characterization of levS, a gene encoding for a levansucrase from Leuconostoc mesenteroides NRRL B-512 F. Gene, 376: 59-67. DOI: 10.1016/j.gene.2006.02.007
Nakapong, S., R. Pichyangkura, K. Ito, M. Iizuka and P. Pongsawasdi, 2013. High expression level of levansucrase from Bacillus licheniformis RN-01 and synthesis of levan nanoparticles. Int. J. Biol. Macromol., 54: 30-36.

DOI: 10.1016/j.ijbiomac. 2012.11.017

Ohtsuku, K., S. Hino, T. Fukushima, O. Ozawa and T. Kanematsu et al., 1992. Characterization of Levansucrase from Rahnella aquatilis JCM-1683. Biosci. Biotech. Biochem., 56: 1373-1377. DOI: $10.1271 / \mathrm{bbb} .56 .1373$

Ozimek, L.K., S. Kralj, M.J.E.C. van der Maarel and L. Dijkhuizen, 2006. The levansucrase and inulo sucrase enzymes of Lactobacillus reuteri 121 catalyse processive and non-processive transglycosylation reactions. Microbiology, 152: 1187-1196. DOI: 10.1099/mic.0.28484-0

Pabst, M.J., 1977. Levan and levansucrase of Actinomyces viscosus. Infect. Immun., 15: 518-526.

Rairakhwada, D., J.W. Seo, M.Y. Seo, O. Kwon and S.K. Rhee et al., 2010. Gene cloning, characterization and heterologous expression of levansucrase from Bacillus amyloliquefaciens. J. Ind. Microbio. Biotechnol., 37: 195-204. DOI: 10.1007/s10295-009-0664-2

Sambrook, J., E.F. Fritsch and T. Maniatis, 1989. Molecular Cloning: A Laboratory Manual. 2nd Edn., Cold Spring Harbor Laboratory Press, New York, ISBN-10: 0879693096.

Sangeetha, P.T., M.N. Ramesh and S.G. Prapulla, 2005. Fructooligosaccharide production using fructosyl transferase obtained from recycling culture of Aspergillus oryzae CFR 202. Process Biochem., 40: 1085-1088. DOI: 10.1016/j.procbio.2004.03.009

Sangiliyandi, G. and P. Gunasekaran, 2000. A simple method for the purification of over-expressed extracellular sucrase of Zymomonas mobilis from a recombinant Escherichia coli. Biotechnol. Lett., 22: 1059-1062. DOI: 10.1023/A:1005693929645

Seibel, J., R. Moraru, S. Gotze, K. Buchholz and S. Naamnieh et al., 2006. Synthesis of sucrose analogues and the mechanism of action of Bacillus subtilis fructosyltransferase (levansucrase). Carbohydr. Res., 341: 2335-2349. DOI: 10.1016/j.carres.2006.07.001

Song, K.B., J.W. Seo, M.G. Kim and S.K. Rhee, 1998. Levansucrase of Rahnella aquatilis ATCC33071: Gene cloning, expression and levan formation. Ann. N.Y. Acad. Sci., 864: 506-511. DOI: 10.1111/j.1749 -6632.1998.tb10369.x

Tamura, K., J. Dudley, M. Nei and S. Kumar, 2007. MEGA4: Molecular Evolutionary Genetics Analysis (MEGA) software version 4.0. Mol. Biol. Evol., 24: 1596-1599. DOI: $10.1093 / \mathrm{molbev} / \mathrm{msm} 092$ 
Tieking, M., M.A. Ehrmann, R.F. Vogel and M.G. Ganzle, 2005. Molecular and functional characterization of a levansucrase from the sourdough isolate Lactobacillus sanfranciscensis TMW 1.392. Appl. Microbiol. Biotechnol., 66: 655-663. DOI: 10.1007/s00253-004-1773-5

Vaidya, V. and D.T. Prasad, 2012. Thermostable levansucrase from Bacillus subtilis BB04, an isolate of banana peel. J. Biochem. Tech., 3: 322-327.

van Hijum, S.A.F.T., E. Szalowska, M.J.E.C. van der Maarel and L. Dijkhuizen, 2004. Biochemical and molecular characterization of a levansucrase from Lactobacillus reuteri. Microbiology, 150: 621-630. DOI: 10.1099/mic.0.26671-0

Velázquez-Hernández, M.L., V.M. Baizabal-Aguirre, A. Bravo-Patiño, M. Cajero-Juárez and M.P. ChávezMoctezuma, 2009. Microbial fructosyltransferases and the role of fructans. J. Appl. Microbiol., 106: 1763-1778. DOI: 10.1111/j.1365-2672.2008.0412 0.x

Viikari, L. and R. Gisler, 1986. By-products in the fermentation of sucrose by different Zymomonasstrains. Appl. Microbiol. Biotechnol., 23: 240-244. DOI: $10.1007 / \mathrm{BF} 00261922$
Waldherr, F.W., D. Meissner and R.F. Vogel, 2008. Genetic and functional characterization of Lactobacillus panis levansucrase. Arch. Microbiol., 190: 497-505. DOI: 10.1007/s00203-008-0404-4

Yanase, H., M. Iwata, R. Nakahigashi, K. Kita and N. Kato et al., 1992. Purification, crystallization and properties of the extracellular levansucrase from Zymomonas mobilis. Biosci. Biotech. Biochem., 56: 1335-1337. DOI: 10.1271/bbb.56.1335

Yoon, E.J., S.H. Yoo, J. Cha and H.G. Lee, 2004. Effect of levan's branching structure on antitumor activity. Int. J. Biol. Macromol., 34: 191-194.

DOI: 10.1016/j.ijbiomac.2004.04.001

Zhang, T., R. Li, H. Qian, W. Mu and M. Miao et al., 2014. Biosynthesis of levan by levansucrase from Bacillus methylotrophicus SK 21.002. Carbohydr. Polym., 101: 975-981. DOI: 10.1016/j.carbpol. 2013.10.045 